\title{
Review \\ The Effect of Continuous Positive Airway Pressure Therapy on Obstructive Sleep Apnea-Related Hypertension
}

\author{
Ronni Baran ${ }^{1}\left(\mathbb{D}\right.$, Daniela Grimm ${ }^{1,2, *(\mathbb{D}}$, Manfred Infanger ${ }^{2}$ and Markus Wehland ${ }^{2, *}$ (i) \\ 1 Department of Biomedicine, Aarhus University, 8000 Aarhus, Denmark; 201709730@post.au.dk \\ 2 Department for Microgravity Research and Translational Regenerative Medicine, Otto-von-Guericke \\ University, D-39106 Magdeburg, Germany; manfred.infanger@med.ovgu.de \\ * Correspondence: dgg@biomed.au.dk (D.G.); markus.wehland@med.ovgu.de (M.W.)
}

check for updates

Citation: Baran, R.; Grimm, D.; Infanger, M.; Wehland, M. The Effect of Continuous Positive Airway Pressure Therapy on Obstructive Sleep Apnea-Related Hypertension. Int. J. Mol. Sci. 2021, 22, 2300. https://doi.org/10.3390/ijms22052300

Academic Editor: Shin Takasawa

Received: 2 February 2021

Accepted: 21 February 2021

Published: 25 February 2021

Publisher's Note: MDPI stays neutral with regard to jurisdictional claims in published maps and institutional affiliations.

Copyright: (c) 2021 by the authors. Licensee MDPI, Basel, Switzerland. This article is an open access article distributed under the terms and conditions of the Creative Commons Attribution (CC BY) license (https:// creativecommons.org/licenses/by/ $4.0 /)$.
Abstract: Obstructive sleep apnea (OSA) is a common disease, with approximately $3-7 \%$ of men and $2-5 \%$ of women worldwide suffering from symptomatic OSA. If OSA is left untreated, hypoxia, microarousals and increased chemoreceptor stimulation can lead to complications like hypertension (HT). Continuous positive airway pressure (CPAP) is the most common treatment for OSA, and it works by generating airway patency, which will counteract the apnea or hypopnea. More than one billion people in the world suffer from HT, and the usual treatment is pharmacological with antihypertensive medication (AHM). The focus of this review will be to investigate whether the CPAP therapy for OSA affects HT.

Keywords: obstructive sleep apnea; hypertension; CPAP

\section{Introduction}

Obstructive sleep apnea (OSA) is the most prevalent type of sleep apnea, and it is a common disease worldwide as well [1]. The most common treatment for OSA is continuous positive airway pressure (CPAP), and this treatment gives a significantly higher health-related quality of life the more adherent patients are [2]. If OSA is left untreated, it can result in complications like hypertension (HT), which can lead to other and more severe health problems like heart failure, stroke and premature death [3]. HT is defined by the European Society of Hypertension (ESH) as systolic blood pressure (SBP) values $>140 \mathrm{mmHg}$ and/or diastolic blood pressure (DBP) values $>90 \mathrm{mmHg}$. As estimated in 2015, HT affects around 1.13 billion people worldwide [4,5].

The standard treatment of HT is either lifestyle changes or pharmacological therapy, and especially pharmacological treatment has some contraindications and adverse effects (AEs). Angiotensin receptor blockers (ARBs), for example, may increase the risk of adverse drug reactions $[4,6]$. As OSA leads to secondary HT, the focus of this review is to investigate if CPAP treatment of OSA affects HT.

\section{Obstructive Sleep Apnea}

OSA is a sleep-related breathing disorder, and the cause of OSA is a repeated obstruction of the upper airways during sleep, which lasts at least $10 \mathrm{~s}$ but can continue for more than a minute. During the obstructive respiratory events, oxygen saturation will decrease, but it will usually return to normal values again. Between $3-7 \%$ of men and $2-5 \%$ of women suffer from OSA-associated daytime sleepiness, while approximately $24 \%$ of men and $9 \%$ of women suffer from OSA without daytime sleepiness. According to the American Academy of Sleep Medicine (AASM), the diagnostic criteria of OSA are five or more obstructive respiratory events per hour of sleep and at least one of the following symptoms: sleepiness during the day, loud snoring, interruptions of breathing during sleep or the patient has been diagnosed with a mood disorder, cognitive dysfunction, stroke, 
atrial fibrillation, type II diabetes mellitus or HT, among others. OSA can also be diagnosed if there are $>15$ obstructive respiratory events per hour of sleep [7].

The degree of OSA can be measured with the Apnea-Hypopnea Index (AHI), which is divided into four degrees of severity based on the number of apneas and hypopneas per hour of sleep as seen in Table $1[8,9]$.

Table 1. The Apnea-Hypopnea Index (AHI).

\begin{tabular}{cc}
\hline Obstructive Sleep Apnea (OSA) Severity & AHI Per Hour of Sleep \\
\hline None/Normal & $<5$ \\
Mild & $5-15$ \\
Moderate & $>15-30$ \\
Severe & $>30$ \\
\hline
\end{tabular}

One way to assess daytime sleepiness quantitatively is by using the Epworth Sleepiness Scale (ESS), which is a subjective questionnaire about how sleepy a person feels in different situations during the day. The patients rate their sleepiness from 0 (would never doze during this activity) to 3 (high chance of dozing during this activity), for eight different activities like watching TV, sitting and talking with someone or riding as a passenger in a car for an hour without a break [10].

\subsection{Causes of Obstructive Sleep Apnea}

\subsubsection{Gender}

As already mentioned, men have a higher prevalence of OSA than women and, therefore, it seems like men are predisposed to OSA. This was shown in Pływaczewski et al., who reported a nearly four times higher prevalence of OSA in males than in females $(p<0.001)$, but both sexes exhibited the same severity of the disease [11]. Tufik et al. reported 4.1-fold higher odds of developing OSA in men than in females $(p<0.001)$ [12].

\subsubsection{Advanced Age}

Age is also an important predisposing factor for OSA. Tufik et al. found that the odds ratio of having OSA is $3.9(p<0.01)$ for 30-39-year-old people, $6.6(p<0.01)$ for 40-49-year-old patients, $10.8(p<0.01)$ for 50-59-year-old people and finally $34.5(p<0.01)$ for 60-80-year-old people as compared to a 20-29-year-old person [12]. This shows a clear relationship between age and OSA. This data fits well with the results from Eikermann et al. who showed that increased age was linked to both an elevation in pharyngeal collapsibility $(p<0.01)$ and an increase in pharyngeal resistance during sleep $(p<0.01)[13]$.

\subsubsection{Obesity and High Body Mass Index}

Heinzer et al. reported a 1.82-fold higher risk of getting mild to severe sleep-disordered breathing (SDB) if the person is a man with a BMI between $25-30 \mathrm{~kg} / \mathrm{m}^{2}$ compared to a man with a BMI $<25 \mathrm{~kg} / \mathrm{m}^{2}(p=0.0132)$. They also found a 4.18 -fold higher risk of getting mild to severe SDB if the person is a man with a BMI $>30 \mathrm{~kg} / \mathrm{m}^{2}$ compared to a man with a BMI $<25 \mathrm{~kg} / \mathrm{m}^{2}(p=0.0062)$. In addition, a woman with a BMI between $25-30 \mathrm{~kg} / \mathrm{m}^{2}$ has a 3.25-fold higher risk of getting mild to severe SDB compared to a woman with a $\mathrm{BMI}<25 \mathrm{~kg} / \mathrm{m}^{2}(p<0.0001)$. A woman with a BMI $>30 \mathrm{~kg} / \mathrm{m}^{2}$ has a $2.43-$ fold higher risk for mild to severe SDB $(p<0.011)$ compared to a woman with a BMI $<25 \mathrm{~kg} / \mathrm{m}^{2}$ [14]. Furthermore, a weight change has an enormous effect on the AHI and the odds of getting SDB [15].

\subsubsection{Other Predisposing Factors}

Moreover, menopause in women, various abnormalities of structures of the head and neck, an exaggerated ventilatory response to a respiratory disturbance, endocrine disorders like hypothyroidism, Down syndrome and some neurological disorders are predisposing and precipitating factors of OSA [7]. 


\section{Hypertension}

There are some differences between the American College of Cardiology (ACC) and American Heart Association (AHA) guidelines for HT and those from the ESH, and this review will follow the locally applied recommendations of the ESH $[4,16]$. The definition of HT depends on the age group and possible sickness, and the ESH defines HT in general as an SBP > $140 \mathrm{mmHg}$ and/or DBP > $90 \mathrm{mmHg}$. Patients with HT above these values can benefit from antihypertensive medication (AHM). It is important to lower blood pressure (BP) because it increases the risk of cardiovascular disease (CVD) [4]. Cardiac output and total peripheral resistance determine BP, but HT is a multifactorial disease, which is affected by genetics and lifestyle, among others. HT can be divided into essential and secondary $\mathrm{HT}$, where the majority of hypertensive patients have essential HT with no underlying identifiable cause. It has been shown that $5-15 \%$ of hypertensive patients have secondary HT, where the cause of the HT is known $[4,17]$. The ESH divides HT into the different grades, which are listed in Table 2.

Table 2. The grades of hypertension.

\begin{tabular}{|c|c|c|c|}
\hline Category & $\begin{array}{l}\text { Systolic Blood } \\
\text { Pressure (SBP) } \\
\text { (mmHg) }\end{array}$ & & $\begin{array}{c}\text { Diastolic Blood } \\
\text { Pressure (DBP) } \\
(\mathrm{mmHg})\end{array}$ \\
\hline Normal blood pressure (BP) & $120-129$ & and/or & $80-84$ \\
\hline High normal BP & $130-139$ & and/or & $85-89$ \\
\hline Grade 1 hypertension & $140-159$ & and/or & 90-99 \\
\hline Grade 2 hypertension & $160-179$ & and/or & $100-109$ \\
\hline Grade 3 hypertension & $\geq 180$ & and/or & $\geq 110$ \\
\hline Isolated systolic hypertension & $\geq 140$ & and & $<90$ \\
\hline
\end{tabular}
Adapted from [4].

\subsection{How Can Obstructive Sleep Apnea Cause Hypertension?}

OSA is a cause of secondary HT, and the risk for HT increases with the severity of OSA. Some researchers have found a dose-response association between SDB at baseline and HT at the end of the follow-up periods of their studies [3,18]. The HT of OSA patients can be treated by the same pharmacological strategies and with the equal effect as HT caused by other reasons than OSA [19].

Since OSA is a complex disease, there are several reasons why BP will rise. Because of hypoxia, sympathetic activity will be increased by the activation of the arterial chemoreceptors, and this will lead to peripheral vasoconstriction, which will increase BP. Furthermore, patients with OSA have a potentiated peripheral chemoreflex response to hypoxia [20]. This sympathetic activation also leads to an activation of the renin-angiotensin-aldosterone system (RAAS), which will increase the levels of aldosterone and plasma angiotensin II, eventually leading to a rise in BP [21].

Patients with OSA also exhibit an endothelial dysfunction. Vasoconstriction and vasorelaxation are unbalanced due to a decreased level of the endothelium-dependent vasodilator nitric oxide (NO). The now decreased antioxidant capacity will lead to a simultaneous rise in oxidative stress, inducing inflammation, which elevates BP [22,23].

At the end of the obstructive respiratory event, there will usually be a microarousal. These microarousals will increase sympathetic activity, and together with oxygen desaturation, this will result in a fragmented sleep. Both the increased sympathetic activity and the fragmented sleep will result in an elevated BP [24]. In addition to the reasons already mentioned, OSA induces insulin resistance, which can also cause a rise in BP [25]. The different mechanisms of OSA leading to HT are shown in Figure 1.

BP of OSA patients often follows a nocturnal nondipping pattern [26,27], which has been shown to be associated with cardiovascular events, coronary events, strokes, cardiovascular mortality and mortality (hazard ratios are 1.57 to 1.89 compared to patients with a dipping nocturnal BP) [28]. 


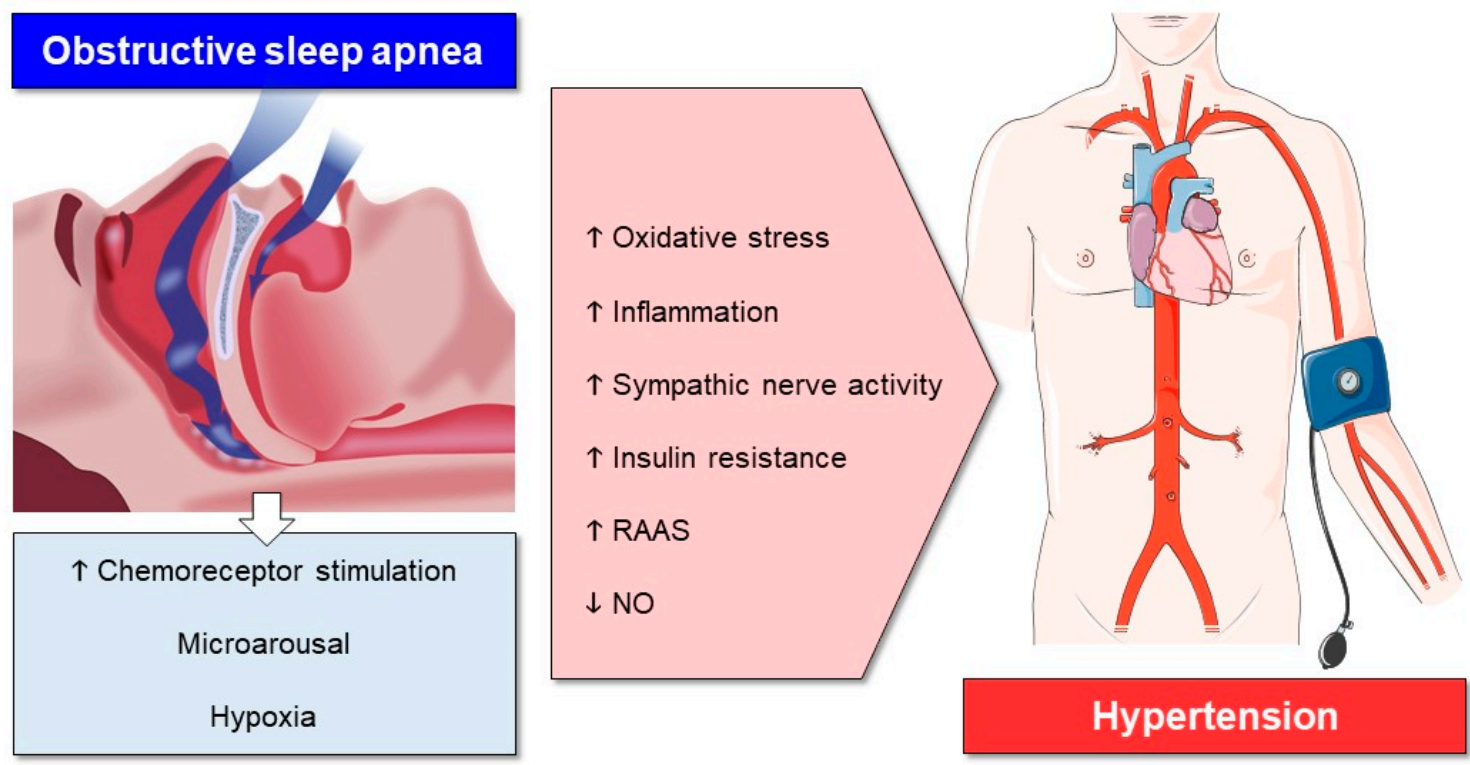

Figure 1. The mechanisms of OSA that lead to hypertension. $\uparrow:$ elevated; $\downarrow$ : reduced. Parts of this figure were produced using graphical elements from Servier Medical Art (available from https://smart.servier.com/), licensed under a Creative Commons Attribution 3.0 Unported License.

On the molecular level, it has been found that hypoxia-inducible factor $1 \alpha(\mathrm{HIF}-1 \alpha)$ serum protein concentration was chronically significantly increased in patients suffering from OSA compared to a healthy control group $[29,30]$. HIF- $1 \alpha$ increases NADPH oxidase 2 (NOX2) mRNA expression, resulting in elevated reactive oxygen species (ROS) abundance, one of the risk factors contributing to the development of hypertension [31]. Furthermore, impaired HIF- $1 \alpha$ serum levels have been implicated in a circadian clock disruption [32] and as a mediator of insulin resistance, type 2 diabetes [33] and consequently of diabetes-related hypertension [34]. Lastly, it has been shown that HIF-1 $\alpha$ is upregulated in pulmonary artery smooth muscle cells of chronically hypoxic mice, driving pulmonary vascular remodeling and pulmonary arterial hypertension [35]. Other studies have proposed an involvement of activated platelets in the development of OSA-related cardiovascular complications [36] and a post hoc miRNA analysis has identified three miRNAs (miR-378a-3p, miR-100-5p and miR-486-5p) that were associated to a favorable CPAP treatment outcome of OSA-related HT. The pathways mostly affected by these miRNAs are the cardiac hypertrophy and NF-kB signaling pathways [37].

\subsection{The Standard Pharmacological Treatment of Hypertension}

The treatment of HT always comprises lifestyle advice, irrespective of the HT grade. The recommended changes in lifestyle are weight loss, regular physical exercise, smoking cessation, moderation of alcohol and dietary changes like sodium restriction and high consumption of fruits and vegetables. Patients with grade 2 or 3 HT will receive pharmacological treatment. High-risk patients with a high normal BP or grade $1 \mathrm{HT}$ suffering of diabetes mellitus and/or CVD will be treated with AHM [4].

AHM is important because a decreased BP is correlated with a lower risk for CVDs including stroke and death $[4,38]$. The ESH recommends five major drug classes to treat HT: beta-adrenoceptor antagonists (BAA), calcium channel blockers (CCBs), angiotensinconverting-enzyme (ACE) inhibitors, ARBs and diuretics [4].

The ACE inhibitors and ARBs lower BP and the risk of CVD events and mortality. These drugs inhibit the RAAS and can delay the progression of chronic kidney disease and lower albuminuria. The drugs can also prevent small artery remodeling and reduce atrial fibrillations and left ventricular hypertrophy $[4,39,40]$. 
CCBs can reduce BP which leads to reduced stroke risk, reduced left ventricular HT, reduced proteinuria and slowed progression of carotid atherosclerosis [4,41]. Diuretics seem more effective than other drug classes to prevent heart failure, and they can reduce $\mathrm{BP}$, which leads to a reduction in CVD events and mortality. The diuretics also lower the serum potassium level but have worse side effects than ACE inhibitors and ARBs [4,42].

BAAs inhibit the beta-adrenoceptors and can significantly reduce the risk of stroke (even though BAA are less effective to prevent stroke than other AHM), heart failure and other CVDs. BAAs have less favorable AEs than RAAS inhibitors but are especially useful in treating HT with symptoms of angina pectoris, tachycardia, heart failure with reduced ejection fraction and infarction, and they can be used as a substitute for ACE inhibitors or ARBs when a woman wants to get pregnant [4,38].

\section{Continuous Positive Airway Pressure (CPAP)}

According to the guidelines about OSA treatment established by both the AASM and the European Respiratory Society, the gold standard treatment is CPAP [43,44]. Patients diagnosed with moderate-to-severe OSA after a home sleep apnea test or an in-laboratory sleep test should start using CPAP right away in order to improve sleepiness and quality of life and to lower BP [44]. CPAP is a flow generator, which can produce a greater air pressure than the surrounding air. The machine is connected to either a nasal, intranasal or oronasal facemask by a tube, and the excess pressure produced by the machine can generate airway patency, which will counteract the apnea or hypopnea the OSA patient experiences. The most recommended mask is the nasal facemask because patients are most adherent to the CPAP treatment with this mask. It is also recommended that the CPAP is humidified because this reduces several AEs. The CPAP is used by the OSA patient while sleeping and it will reduce the number of obstructive events, oxygen desaturation and sleep fragmentation. The decrease in sleep fragmentation will help the OSA patient to overcome OSA symptoms. In addition to the CPAP treatment, OSA patients are also advised to lose weight, cease smoking and avoid alcohol $[44,45]$. Examples of CPAP machines and facial masks can be seen in Figure 2.
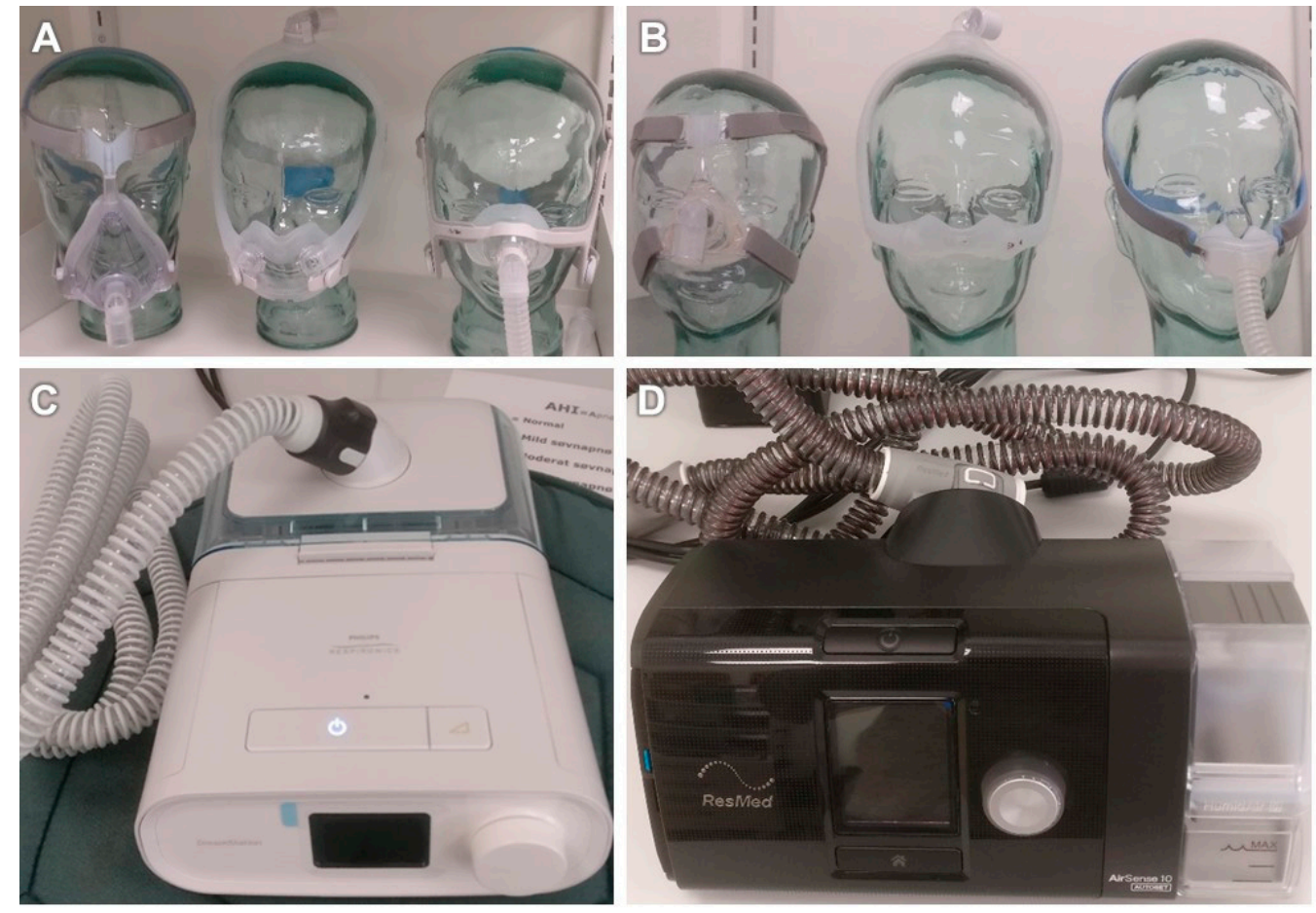

Figure 2. Continuous positive airway pressure (CPAP) machines and masks. (A) Nasal and oronasal masks, (B) nasal masks, (C) Philips CPAP machine and (D) ResMed CPAP machine. 
There are other methods and devices suitable to treat OSA. These include increasing the pharyngeal space with oral appliances if the OSA patient is intolerant to the CPAP therapy. However, oral applications are less effective than CPAP $[45,46]$. Another treatment option of OSA is surgical modifications of the upper airway to increase the airway surface area and to remove the airway obstruction, but many surgical techniques only partially correct SDB in contrast to CPAP, which exhibits a much higher success rate [45,47]. A further option is medical therapy for OSA, but only topical nasal corticosteroids are recommended by the AASM [48].

\subsection{The Effect of Continuous Positive Airway Pressure on Hypertension}

CPAP treatment showed a decreasing effect on BP in several studies. Kartali et al. found after three months of CPAP therapy a reduction in mean SBP from $141.5 \pm 12.1$ to $133.5 \pm 9.7 \mathrm{mmHg}$ ( $p=0.007$ ) (only during the night) and a decrease in DBP from $87.8 \pm 6.8$ to $83 \pm 1.4(p=0.004)$ (during day and night). Furthermore, heart rate decreased in OSA patients to the frequency of the normotensive control group [49]. Hoyos et al. measured a significantly reduced BP after CPAP therapy as well, which was not influenced by daytime (morning or evening). They also reported a reduced mean central SBP of $-4.1 \mathrm{mmHg}(p=0.003)$, mean central DBP of $-3.9 \mathrm{mmHg}(p=0.0009)$, mean peripheral SBP of $-4.1 \mathrm{mmHg}(p=0.004)$ and a decreased mean peripheral DBP of $-3.8 \mathrm{mmHg}$ $(p=0.001)$ [50]. Moreover, Huang et al. examined patients with coronary heart disease and OSA and measured a significantly reduced SBP of $5.6 \mathrm{mmHg}(p<0.001)$ and DBP of $3.0 \mathrm{mmHg}(p=0.009)$ [51].

Yang et al. reported a correlation between CPAP adherence and morning mean BP (MBP) over the four years the study lasted. In patients with high adherence to the CPAP therapy ( $>4 \mathrm{~h}$ of use per night for $>70 \%$ of the nights monitored), there was decreased MBP from $100.8 \pm 13.6 \mathrm{mmHg}$ to $96.6 \pm 10.8 \mathrm{mmHg}(p=0.004)$. In contrast, patients with no CPAP treatment exhibited a significant increase in MBP [52]. Furthermore, Yang et al. detected a significantly decreased ESS score (from $11.1 \pm 5.6$ to $9.5 \pm 4.9(p=0.006)$ ), AHI (from $54.8 \pm 21.2$ episodes per hour of sleep to $39.7 \pm 21.4$ episodes per hour of sleep $(p<0.001)$ ) and oxygen desaturation index (ODI) (from $46.8 \pm 24.8$ episodes per hour to $33.9 \pm 20.5$ episodes per hour) in the high CPAP adherence group. Meanwhile, in the no-treatment group there was no significant change in ESS score or AHI, but there was an increased ODI from $35.0 \pm 21.4$ episodes per hour to $42.7 \pm 24.1(p=0.02)$ [52].

Huang et al. also found a significantly reduced ESS score after CPAP therapy [51], while Møller et al. showed a significant difference in AHI and ODI between a group of OSA patients without CPAP therapy and a group of OSA patients with CPAP therapy. AHI was $30.1 \pm 5.8$ episodes per hour of sleep for the group without CPAP therapy and $0.9 \pm 0.3$ for the group with CPAP therapy $(p<0.001)$, and ODI was $34.9 \pm 5.1$ for the group without CPAP therapy and $7.4 \pm 2.9$ for the group with CPAP therapy $(p<0.001)$ [21].

OSA can lead to oxidative stress and a decreased amount of NO. This results in HT [22,23]. CPAP affects both the level of NO and the oxidative stress positively so that $\mathrm{BP}$ is decreased. Ip et al. found a significant increase in the level of serum NO after one night of CPAP therapy. The level of serum NO was not significantly different from the level of serum NO of the healthy control subjects [22]. In addition, Barceló et al. reported a significantly elevated total antioxidant status after 12 months of CPAP therapy, while the $\gamma$-glutamyl transferase was decreased significantly from $36 \pm 15 \mathrm{U} / \mathrm{L}$ to $30 \pm 14 \mathrm{U} / \mathrm{L}$, and none of these changes differed from those of the healthy control group [23]. Schulz et al. demonstrated in OSA patients after $4.8 \pm 0.6$ months of CPAP therapy that the concentration of superoxide in neutrophils isolated from blood samples was significantly reduced [53]. The reduction in superoxide concentration and $\gamma$-glutamyl transferase as well as the increased total antioxidant status lead to lower oxidative stress and therefore to a lower BP. 
4.2. Comparison between the Effects and Side Effects of Continuous Positive Airway Pressure and the Standard Pharmacological Treatment of Hypertension

Focusing on the effect of CPAP treatment on HT, Kartali et al. and Hoyos et al. found a reduction in SBP of -8 and $-4.1 \mathrm{mmHg}$ and a decrease in DBP of -4.8 and $-3.9 \mathrm{mmHg}$, respectively $[49,50]$. Several studies reported on the efficacy of AHM in OSA patients. Zou et al. studied the ACE inhibitor enalapril and found a significant reduction in SBP of $-12.6 \pm 15.9 \mathrm{mmHg}$ and DBP of $-8.9 \pm 6.5 \mathrm{mmHg}$ in OSA patients with HT [54].

In addition, Pépin et al. have studied the effect of the ARB valsartan in OSA patients with HT who had never used AHM and CPAP. The authors measured a reduction in 24-h SBP of $-10.6 \mathrm{mmHg}(p<0.001), 24-\mathrm{h}$ DBP of $-8.4 \mathrm{mmHg}(p<0.001)$ and a decrease in 24-h MBP of $-9.1 \pm 7.2 \mathrm{mmHg}(p<0.001)$. Valsartan did also significantly reduce both daytime and night-time SBP, DBP and MBP as well as 24-h heart rate. Moreover, Pépin et al. compared the effect of valsartan with CPAP therapy and detected an overall significant difference in the 24-h, daytime and night-time SBP, DBP and MBP, but not in the 24-h heart rate, where valsartan decreased BP more than CPAP therapy [55].

In summary, these studies show that AHM has the most decreasing effect on BP, but CPAP therapy still has an effect when applied alone.

Almost all treatments have AEs and neither CPAP therapy nor AHM can avoid that. The AEs of CPAP therapy are listed in Table 3, while the AEs of AHM are given in Table 4.

Table 3. Examples of adverse effects (AEs) of CPAP therapy.

\begin{tabular}{cc}
\hline CPAP without Humidification & CPAP with Humidification \\
\hline Bleeding nose & Wry nose \\
Nasal congestion and discharge & Water condensation on the face \\
Headaches & Water condensation in the nose \\
Dry mouth & Water condensation in the mouth \\
Dry and sore throat & \\
Pain in sinuses & \\
Reduced smell & \\
Changed voice & \\
\hline Modified from [4].
\end{tabular}

Table 4. Examples of AEs of the five major classes of antihypertensive medication (AHM).

\begin{tabular}{|c|c|c|c|c|c|}
\hline $\begin{array}{c}\text { ACE } \\
\text { Inhibitors }\end{array}$ & $\begin{array}{c}\text { Lipophilic } \\
\text { Beta-Adrenoreceptor } \\
\text { Antagonists (BAAs) }\end{array}$ & $\begin{array}{c}\text { Hydrophilic } \\
\text { BAA }\end{array}$ & $\begin{array}{l}\text { Calcium Channel } \\
\text { Blockers (CCBs) }\end{array}$ & $\begin{array}{c}\text { Angiotensin } \\
\text { Receptor Blockers } \\
\text { (ARBs) }\end{array}$ & Diuretics \\
\hline Coughing [56] & $\begin{array}{l}\text { Difficulties staying } \\
\text { asleep [57] }\end{array}$ & Dyspepsia [58] & Flushing [58] & $\begin{array}{l}\text { No significant } \\
\text { differences to } \\
\text { placebo [59] }\end{array}$ & Dizziness [60] \\
\hline Dizziness [56] & Restless nights [57] & Diarrhea [58] & Edema [58] & Headache [61] & $\begin{array}{c}\text { Male gynecomastia } \\
{[60]}\end{array}$ \\
\hline Angioedema [56] & $\begin{array}{l}\text { Sexual intercourse } \\
\text { problems [57] }\end{array}$ & Fatigue [58] & Fatigue [58] & Fatigue [61] & $\begin{array}{c}\text { Male impotence } \\
{[60]}\end{array}$ \\
\hline \multirow[t]{3}{*}{$\begin{array}{c}\text { Renal } \\
\text { dysfunction [56] }\end{array}$} & & Dyspnea [58] & Dyspnea [58] & Dizziness [61] & Hyperkalemia [60] \\
\hline & & Dizziness [58] & Dizziness [58] & Back pain [61] & $\begin{array}{c}\text { Orthostatic } \\
\text { hypotension [60] }\end{array}$ \\
\hline & & Headaches [58] & Headaches [58] & & Dyspepsia [60] \\
\hline
\end{tabular}


AHM has a significantly better effect on SBP, DBP and MBP than CPAP, but there is evidence that the use of AHM in combination with CPAP has an additional positive effect. Pépin et al., investigating OSA patients with HT who never used AHM or CPAP, showed that $61 \%$ of the patients, adherent to CPAP therapy, were not treated sufficiently during all $24 \mathrm{~h}$ by monotherapy of ARB or CPAP. Therefore, they applied a combination of ARB and CPAP therapy, and this induced a significant reduction in office SPB, DBP and MBP compared to the ARB and CPAP groups alone [55]. Thunström et al. studied a population of OSA patients with newly diagnosed HT and gave one group losartan (an ARB) and another group both losartan and CPAP. The BP-lowering effect of losartan alone was significantly smaller in patients with OSA compared to those without. Furthermore, they observed a significant reduction in mean 24-h SBP, DBP and MBP in patients treated with losartan + CPAP for $>4 \mathrm{~h}$ per night (per protocol-population) vs. losartan alone. In the intention-to-treat population, they only found a significant decrease in mean night-time SBP and mean morning SBP [62].

These studies show that the combination of AHM and CPAP has an added positive effect on OSA patients with HT, but this effect might only be seen when the patient is adherent to the treatment.

\subsection{Clinical Trials Investigating the Effect of Continuous Positive Airway Pressure in Treatment of Hypertension}

An overview of the latest clinical trials of OSA and HT is given in Table 5. Most of the studies focus on the effect of CPAP therapy.

Table 5. An overview of the latest clinical trials of OSA and HT.

\begin{tabular}{|c|c|c|c|c|}
\hline $\begin{array}{c}\text { Title and Identification } \\
\text { Number }\end{array}$ & Participants & Design & Objective & Status/Conclusions \\
\hline $\begin{array}{l}\text { Untreated Obstructive Sleep } \\
\text { Apnea Is Associated With } \\
\text { Myocardial Injury } \\
\text { Independent of Blood } \\
\text { Pressure Control in } \\
\text { Hypertension } \\
\text { (NCT00843583) }\end{array}$ & 98 & $\begin{array}{c}\text { Observational } \\
\text { Case-Only } \\
\text { Cross-sectional Study }\end{array}$ & $\begin{array}{l}\text { Find the prevalence of } \\
\text { OSA between resistant } \\
\text { hypertension patients. } \\
\text { The aim is also to } \\
\text { assess the relation } \\
\text { be-tween the severity } \\
\text { of OSA and BP control. }\end{array}$ & $\begin{array}{c}\text { Completed. } \\
\text { In patients with } \\
\text { difficult-to-control HT, it was } \\
\text { common to find } \\
\text { unrecognized severe OSA, } \\
\text { and the severity of OSA was } \\
\text { associated with myocardial } \\
\text { injury. }\end{array}$ \\
\hline $\begin{array}{l}\text { Effects of OSA Treatment on } \\
\text { BP in Patients With Resistant } \\
\text { Hyper-tension: A } \\
\text { Randomized Trial } \\
\text { (NCT00812695) }\end{array}$ & 40 & $\begin{array}{c}\text { Interventional } \\
\text { Randomized Parallel } \\
\text { assignment No } \\
\text { masking Study } \\
\text { Phase III }\end{array}$ & $\begin{array}{l}\text { Investigate CPAP } \\
\text { therapy effect on BP } \\
\text { control in patients with } \\
\text { OSA and refractory } \\
\text { hypertension. The aim } \\
\text { is also to study how } \\
\text { CPAP therapy affects } \\
\text { arterial stiffness and } \\
\text { cardiac remodeling. }\end{array}$ & $\begin{array}{c}\text { Completed. } \\
\text { CPAP therapy on patients } \\
\text { with resistant HT } \\
\text { significantly reduces the } \\
\text { daytime BP. }\end{array}$ \\
\hline $\begin{array}{c}\text { Effects of Continuous } \\
\text { Positive Airway Pressure } \\
\text { Treatment on Aldosterone } \\
\text { Excretion in Patients With } \\
\text { Obstructive Sleep Apnoea } \\
\text { and Resistant Hypertension: } \\
\text { A Randomized Controlled } \\
\text { Trial } \\
\text { (NCT01508754) }\end{array}$ & 125 & $\begin{array}{c}\text { Interventional } \\
\text { Randomized-Parallel } \\
\text { Assignment Single } \\
\text { Masked Study } \\
\text { Phase IV }\end{array}$ & $\begin{array}{c}\text { Investigate CPAP } \\
\text { therapy effect on BP } \\
\text { (both ambulatory and } \\
\text { clinical) on patients } \\
\text { with OSA and resistant } \\
\text { hypertension. }\end{array}$ & $\begin{array}{c}\text { Completed. } \\
\text { Significantly reduced } \\
\text { aldosterone excretion in } \\
\text { patients with uncontrolled } \\
\text { resistant HT only under } \\
\text { optimal CPAP (per protocol } \\
\text { group). The effect was } \\
\text { borderline significant in the } \\
\text { intention-to-treat group } \\
{[63,64] .}\end{array}$ \\
\hline
\end{tabular}


Table 5. Cont.

\begin{tabular}{|c|c|c|c|c|}
\hline $\begin{array}{c}\text { Title and Identification } \\
\text { Number }\end{array}$ & Participants & Design & Objective & Status/Conclusions \\
\hline $\begin{array}{l}\text { Effects of CPAP on } \\
\text { "Vascular" Risk Factors in } \\
\text { Patients With Obstructive } \\
\text { Sleep Apnea and Arterial } \\
\text { Hypertension } \\
\text { (NCT00801671) }\end{array}$ & 44 & $\begin{array}{c}\text { Interventional } \\
\text { Randomized } \\
\text { Crossover } \\
\text { Assignment } \\
\text { Double-blind Study } \\
\text { Phase III }\end{array}$ & $\begin{array}{c}\text { Investigate CPAP } \\
\text { therapy effectiveness in } \\
\text { treating systemic } \\
\text { hypertension. }\end{array}$ & $\begin{array}{l}\text { Completed. } \\
\text { In a group of OSA patients } \\
\text { with HT, three weeks of } \\
\text { effective CPAP therapy gave } \\
\text { a significant decrease in } \\
\text { office BP, central BP and } \\
\text { augmentation index, and } \\
\text { there was an improvement of } \\
\text { arterial stiffness parameters. }\end{array}$ \\
\hline $\begin{array}{l}\text { Long-term Effects of } \\
\text { Continuous Positive Airway } \\
\text { Pressure on Blood Pressure } \\
\text { and Prognosis in } \\
\text { Hypertensive Patients With } \\
\text { Coronary Heart Disease and } \\
\text { Obstructive Sleep Apnea: A } \\
\text { Randomized Controlled Trial } \\
\text { (NCT02059993) }\end{array}$ & 83 & $\begin{array}{c}\text { Interventional } \\
\text { Randomized Parallel } \\
\text { Assignment Single } \\
\text { Masked Study }\end{array}$ & $\begin{array}{l}\text { Evaluate the effect of } \\
\text { CPAP therapy on BP, } \\
\text { cerebrovascular events, } \\
\text { metabolic disorder and } \\
\text { cardiovascular events } \\
\text { in patients who were } \\
\text { suffering from OSA } \\
\text { and coronary heart } \\
\text { disease who used } \\
\text { conventional treatment. }\end{array}$ & $\begin{array}{l}\text { Completed. } \\
\text { In patients with uncontrolled } \\
\text { HT, coronary heart disease } \\
\text { and OSA, long-term CPAP } \\
\text { therapy reduces daytime } \\
\text { SBP. }\end{array}$ \\
\hline
\end{tabular}

\section{Discussion}

The studies mentioned above show that both AHM and CPAP significantly reduce $\mathrm{BP}$. Even though CPAP supports the lowering of BP, AHM is indicated in patients with OSA and hypertension because AHM lowers BP significantly more than CPAP therapy. However, CPAP therapy also has some other beneficial effects like lowering the ESS score, AHI and ODI [52]. Furthermore, it increases the quality of life [2]. Therefore, the use of CPAP therapy is highly relevant in OSA patients.

As already published earlier by Yang et al., the patients' adherence is important, as CPAP therapy only induces beneficial effects on MBP and sleep quality when the OSA patients were adherent to the treatment [52]. A meta-analysis by Rotenberg et al. showed that between 1994 and 2000, nonadherence rates only slowly improved from about 50\% to about $30 \%$, where they remained virtually unchanged until the study ended in 2015, despite many efforts in patient coaching and improvements on CPAP machines and masks [65]. To a certain extent, the adherence can be influenced by AEs, and when comparing the AEs of CPAP therapy and AHM, the AEs of the AHM are more severe than those for CPAP. The AEs of AHM can have a devastating impact on a person's health and quality of life, while the AE of CPAP therapy are only minor irritations and pains. The severity of AEs is quite important when considering adherence to therapy. Lipophilic BAAs will especially be a problem for OSA patients because their CNS-related AEs can negatively affect sleep. However, due to the multitude of different antihypertensive drugs, it is possible to switch to another medication upon the onset of any given severe $\mathrm{AE}$ in order to maintain compliance without compromising the pharmacological therapy as whole.

CPAP therapy is always indicated against OSA irrespective of existing HT because of its beneficial effects on ESS score, AHI and ODI among OSA patients. CPAP therapy might be enough in lowering grades of HT to a normal BP, but it does not seem capable of lowering higher grades sufficiently. Therefore, the combined effect of AHM and CPAP therapy can be used in patients where CPAP therapy is not effective enough to lower BP to a normal range. 


\section{Methods}

For this review, a literature search was performed by using online repositories and clinical trials. The literature search was performed on PubMed (pubmed.ncbi.nlm.nih.gov), scopus.com and clinicaltrials.gov. The search included only English, Danish and Norwegian papers, which can lead to language bias, and because the search only included published papers, there is a risk of publication bias. Additional papers were found in "similar articles", "cited by" and reference lists of the primary articles.

\section{Conclusions and Outlook}

OSA is an important cause of developing HT. HT can lead to severe CVDs. Therefore, the treatment of both OSA and HT is very important. To a certain degree, HT can be treated with CPAP, but AHM was shown to lower BP significantly more than CPAP therapy. In some studies, CPAP therapy revealed effects on the nightly BP only, while AHM showed an impact on the 24-h BP. The superior effect of AHM is accompanied by more severe AEs than CPAP treatment. Depending on the drug, examples for AEs are renal dysfunction, flushing, edema and hyperkalemia, whereas the severest AEs of CPAP therapy are a bleeding nose, pain in the sinuses, headache and a dry mouth. In parallel, CPAP treatment can lower BP and decrease ESS score, AHI and ODI as well as increase quality of life. These parameters are very important for OSA patients. Therefore, CPAP therapy is still very beneficial for OSA patients.

In conclusion, the best treatment of OSA patients with HT is a combination therapy of both AHM and CPAP therapy, which has demonstrated a significant additive effect on $\mathrm{BP}$, and CPAP has improved the well-being of OSA patients.

OSA will continue to be a major health issue. Because of the risk to develop HT, it is important to diagnose OSA earlier than we do today, since this will reduce the risk of getting CVDs. Furthermore, it is important to study the exact mechanisms leading to OSA and the mechanisms that lower BP while using CPAP. If the mechanisms that lead to OSA are known, OSA can be diagnosed before it induces HT. When the mechanisms for lowering $\mathrm{BP}$ while using CPAP treatment are known, then this knowledge can improve HT therapy in OSA patients.

CPAP therapy and AHM have AEs, which can diminish the patients' adherence to the therapy. Therefore, developing novel AHM with fewer AEs might be favorable because this can heighten the patients' well-being and quality of life. Moreover, further improvements of CPAP machines are necessary so that more patients will tolerate it.

Author Contributions: All authors contributed to the review and search of the literature. Conceptualisation, R.B., M.W., and D.G.; Investigation, R.B.; Writing—original draft preparation, R.B.; Review and editing, M.W., and D.G.; Visualisation, R.B.; Project administration, D.G.; Funding acquisition, D.G., and M.I. All authors have read and agreed to the published version of the manuscript.

Funding: This research was funded by Deutsches Zentrum für Luft- und Raumfahrt, grant number: 50WB1924.

Institutional Review Board Statement: Not applicable.

Informed Consent Statement: Not applicable.

Conflicts of Interest: The authors declare no conflict of interest. 


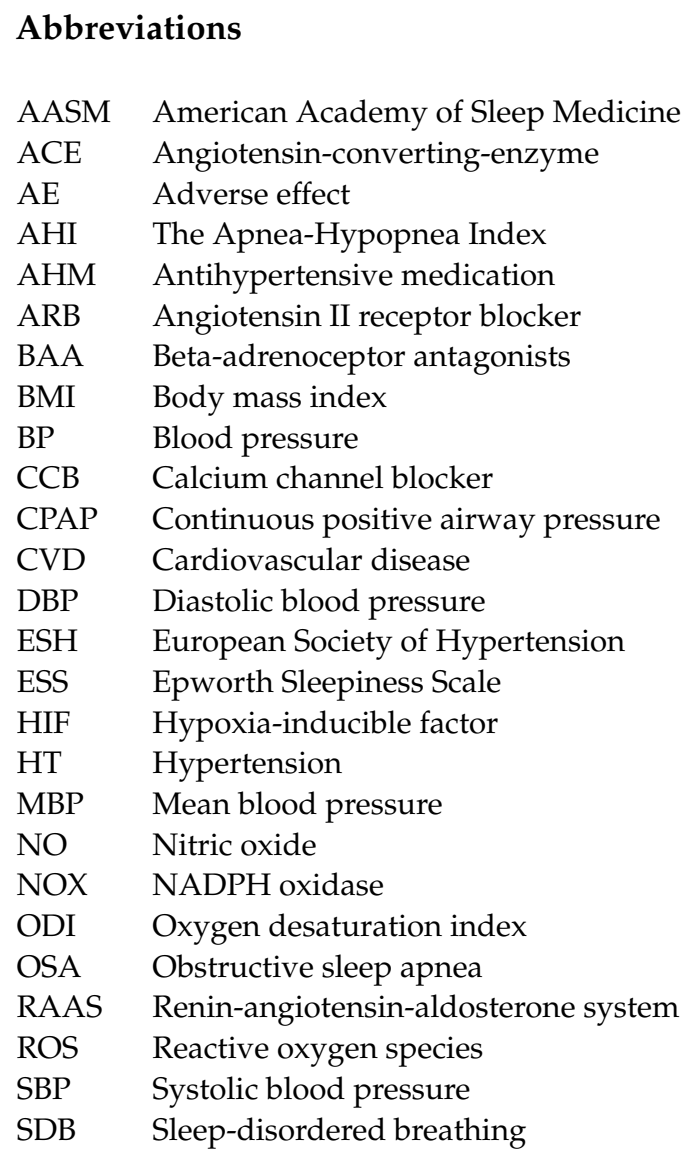

\section{References}

1. Donovan, L.M.; Kapur, V.K. Prevalence and Characteristics of Central Compared to Obstructive Sleep Apnea: Analyses from the Sleep Heart Health Study Cohort. Sleep 2016, 39, 1353-1359. [CrossRef]

2. Lo Bue, A.; Salvaggio, A.; Iacono Isidoro, S.; Romano, S.; Insalaco, G. OSA and CPAP therapy: Effect of gender, somnolence, and treatment adherence on health-related quality of life. Sleep Breath 2020, 24, 533-540. [CrossRef]

3. Tveit, R.L.; Lehmann, S.; Bjorvatn, B. Prevalence of several somatic diseases depends on the presence and severity of obstructive sleep apnea. PLoS ONE 2018, 13, e0192671. [CrossRef]

4. Williams, B.; Mancia, G.; Spiering, W.; Agabiti Rosei, E.; Azizi, M.; Burnier, M.; Clement, D.L.; Coca, A.; de Simone, G.; Dominiczak, A.; et al. 2018 ESC/ESH Guidelines for the management of arterial hypertension. Eur. Heart J. 2018, 39, 3021-3104. [CrossRef] [PubMed]

5. NCD Risk Factor Collaboration. Worldwide trends in blood pressure from 1975 to 2015: A pooled analysis of 1479 populationbased measurement studies with 19.1 million participants. Lancet 2017, 389, 37-55. [CrossRef]

6. Alhawassi, T.M.; Krass, I.; Pont, L.G. Antihypertensive-related adverse drug reactions among older hospitalized adults. Int. J. Clin. Pharm. 2018, 40, 428-435. [CrossRef] [PubMed]

7. American Academy of Sleep Medicine. International Classification of Sleep Disorders_Third Edition (ICSD-3), 3rd ed.; American Academy of Sleep Medicine: Darien, IL, USA, 2014.

8. Ruehland, W.R.; Rochford, P.D.; O'Donoghue, F.J.; Pierce, R.J.; Singh, P.; Thornton, A.T. The new AASM criteria for scoring hypopneas: Impact on the apnea hypopnea index. Sleep 2009, 32, 150-157. [CrossRef]

9. Quan, S.F.; Gillin, J.C.; Littner, M.R.; Shepard, J.W. Sleep-related breathing disorders in adults: Recommendations for syndrome definition and measurement techniques in clinical research. The Report of an American Academy of Sleep Medicine Task Force. Sleep 1999, 22, 667-689.

10. Johns, M.W. A new method for measuring daytime sleepiness: The Epworth sleepiness scale. Sleep 1991, 14, 540-545. [CrossRef] [PubMed]

11. Pływaczewski, R.; Bednarek, M.; Jonczak, L.; Zieliński, J. Sleep-disordered breathing in a middle-aged and older Polish urban population. J. Sleep Res. 2008, 17, 73-81. [CrossRef]

12. Tufik, S.; Santos-Silva, R.; Taddei, J.A.; Bittencourt, L.R. Obstructive sleep apnea syndrome in the Sao Paulo Epidemiologic Sleep Study. Sleep Med. 2010, 11, 441-446. [CrossRef]

13. Eikermann, M.; Jordan, A.S.; Chamberlin, N.L.; Gautam, S.; Wellman, A.; Lo, Y.L.; White, D.P.; Malhotra, A. The influence of aging on pharyngeal collapsibility during sleep. Chest 2007, 131, 1702-1709. [CrossRef] [PubMed] 
14. Heinzer, R.; Vat, S.; Marques-Vidal, P.; Marti-Soler, H.; Andries, D.; Tobback, N.; Mooser, V.; Preisig, M.; Malhotra, A.; Waeber, G.; et al. Prevalence of sleep-disordered breathing in the general population: The HypnoLaus study. Lancet Respir. Med. 2015, 3, 310-318. [CrossRef]

15. Peppard, P.E.; Young, T.; Palta, M.; Dempsey, J.; Skatrud, J. Longitudinal study of moderate weight change and sleep-disordered breathing. JAMA 2000, 284, 3015-3021. [CrossRef]

16. Whelton, P.K.; Carey, R.M.; Aronow, W.S.; Casey, D.E., Jr.; Collins, K.J.; Dennison Himmelfarb, C.; DePalma, S.M.; Gidding, S.; Jamerson, K.A.; Jones, D.W.; et al. 2017 ACC/AHA/AAPA/ABC/ACPM/AGS/APhA/ASH/ASPC/NMA/PCNA Guideline for the Prevention, Detection, Evaluation, and Management of High Blood Pressure in Adults: Executive Summary: A Report of the American College of Cardiology / American Heart Association Task Force on Clinical Practice Guidelines. Hypertension 2018, 71, 1269-1324.

17. Padmanabhan, S.; Caulfield, M.; Dominiczak, A.F. Genetic and molecular aspects of hypertension. Circ. Res. 2015, 116, 937-959. [CrossRef]

18. Peppard, P.E.; Young, T.; Palta, M.; Skatrud, J. Prospective study of the association between sleep-disordered breathing and hypertension. N. Engl. J. Med. 2000, 342, 1378-1384. [CrossRef]

19. Fatureto-Borges, F.; Jenner, R.; Costa-Hong, V.; Lopes, H.F.; Teixeira, S.H.; Marum, E.; Giorgi, D.A.M.; Consolim-Colombo, F.M.; Bortolotto, L.A.; Lorenzi-Filho, G.; et al. Does Obstructive Sleep Apnea Influence Blood Pressure and Arterial Stiffness in Response to Antihypertensive Treatment? Hypertension 2018, 72, 399-407. [CrossRef]

20. Narkiewicz, K.; van de Borne, P.J.; Pesek, C.A.; Dyken, M.E.; Montano, N.; Somers, V.K. Selective potentiation of peripheral chemoreflex sensitivity in obstructive sleep apnea. Circulation 1999, 99, 1183-1189. [CrossRef] [PubMed]

21. Møller, D.S.; Lind, P.; Strunge, B.; Pedersen, E.B. Abnormal vasoactive hormones and 24-h blood pressure in obstructive sleep apnea. Am. J. Hypertens. 2003, 16, 274-280. [CrossRef]

22. Ip, M.S.; Lam, B.; Chan, L.Y.; Zheng, L.; Tsang, K.W.; Fung, P.C.; Lam, W.K. Circulating nitric oxide is suppressed in obstructive sleep apnea and is reversed by nasal continuous positive airway pressure. Am. J. Respir. Crit. Care Med. 2000, 162, $2166-2171$. [CrossRef]

23. Barceló, A.; Barbé, F.; de la Peña, M.; Vila, M.; Pérez, G.; Piérola, J.; Durán, J.; Agustí, A.G. Antioxidant status in patients with sleep apnoea and impact of continuous positive airway pressure treatment. Eur. Respir. J. 2006, 27, 756-760. [CrossRef]

24. Noda, A.; Yasuma, F.; Okada, T.; Yokota, M. Influence of movement arousal on circadian rhythm of blood pressure in obstructive sleep apnea syndrome. J. Hypertens. 2000, 18, 539-544. [CrossRef]

25. Ip, M.S.; Lam, B.; Ng, M.M.; Lam, W.K.; Tsang, K.W.; Lam, K.S. Obstructive sleep apnea is independently associated with insulin resistance. Am. J. Respir. Crit. Care Med. 2002, 165, 670-676. [CrossRef]

26. Mokhlesi, B.; Hagen, E.W.; Finn, L.A.; Hla, K.M.; Carter, J.R.; Peppard, P.E. Obstructive sleep apnoea during REM sleep and incident non-dipping of nocturnal blood pressure: A longitudinal analysis of the Wisconsin Sleep Cohort. Thorax 2015, 70, 1062-1069. [CrossRef]

27. Loredo, J.S.; Ancoli-Israel, S.; Dimsdale, J.E. Sleep quality and blood pressure dipping in obstructive sleep apnea. Am. J. Hypertens. 2001, 14 Pt 1, 887-892. [CrossRef]

28. Salles, G.F.; Reboldi, G.; Fagard, R.H.; Cardoso, C.R.; Pierdomenico, S.D.; Verdecchia, P.; Eguchi, K.; Kario, K.; Hoshide, S.; Polonia, J.; et al. Prognostic Effect of the Nocturnal Blood Pressure Fall in Hypertensive Patients: The Ambulatory Blood Pressure Collaboration in Patients with Hypertension (ABC-H) Meta-Analysis. Hypertension 2016, 67, 693-700. [CrossRef]

29. Gabryelska, A.; Szmyd, B.; Szemraj, J.; Stawski, R.; Sochal, M.; Białasiewicz, P. Patients with obstructive sleep apnea present with chronic upregulation of serum HIF-1 $\alpha$ protein. J. Clin. Sleep Med. 2020, 16, 1761-1768. [CrossRef] [PubMed]

30. Gabryelska, A.; Szmyd, B.; Panek, M.; Szemraj, J.; Kuna, P.; Białasiewicz, P. Serum hypoxia-inducible factor-1 $\alpha$ protein level as a diagnostic marker of obstructive sleep apnea. Pol. Arch. Intern. Med. 2020, 130, 158-160. [CrossRef]

31. Touyz, R.M.; Briones, A.M. Reactive oxygen species and vascular biology: Implications in human hypertension. Hypertens. Res. 2011, 34, 5-14. [CrossRef]

32. Gabryelska, A.; Sochal, M.; Turkiewicz, S.; Białasiewicz, P. Relationship between HIF-1 and Circadian Clock Proteins in Obstructive Sleep Apnea Patients-Preliminary Study. J. Clin. Med. 2020, 9, 1599. [CrossRef]

33. Gabryelska, A.; Karuga, F.F.; Szmyd, B.; Białasiewicz, P. HIF-1 $\alpha$ as a Mediator of Insulin Resistance, T2DM, and Its Complications: Potential Links with Obstructive Sleep Apnea. Front. Physiol. 2020, 11, 1035. [CrossRef]

34. Wang, F.; Han, L.; Hu, D. Fasting insulin, insulin resistance and risk of hypertension in the general population: A meta-analysis Clin. Chim. Acta 2017, 464, 57-63. [CrossRef]

35. Luo, Y.; Teng, X.; Zhang, L.; Chen, J.; Liu, Z.; Chen, X.; Zhao, S.; Yang, S.; Feng, J.; Yan, X. CD146-HIF-1 $\alpha$ hypoxic reprogramming drives vascular remodeling and pulmonary arterial hypertension. Nat. Commun. 2019, 10, 3551. [CrossRef] [PubMed]

36. Gabryelska, A.; Łukasik, Z.M.; Makowska, J.S.; Białasiewicz, P. Obstructive Sleep Apnea: From Intermittent Hypoxia to Cardiovascular Complications via Blood Platelets. Front. Neurol. 2018, 9, 635. [CrossRef] [PubMed]

37. Zapater, A.; Santamaria-Martos, F.; Targa, A.; Pinilla, L.; Sánchez-de-la-Torre, A.; Benítez, I.D.; Martínez-García, M.Á.; Barbé, F.; Sánchez-de-la-Torre, M. Canonical Pathways Associated with Blood Pressure Response to Sleep Apnea Treatment: A Post Hoc Analysis. Respiration 2021, Feb 5, 1-10, Epub ahead of print. [CrossRef]

38. Dahlöf, B.; Lindholm, L.H.; Hansson, L.; Scherstén, B.; Ekbom, T.; Wester, P.O. Morbidity and mortality in the Swedish Trial in Old Patients with Hypertension (STOP-Hypertension). Lancet 1991, 338, 1281-1285. [CrossRef] 
39. Yusuf, S.; Teo, K.; Anderson, C.; Pogue, J.; Dyal, L.; Copland, I.; Schumacher, H.; Dagenais, G.; Sleight, P. Effects of the angiotensinreceptor blocker telmisartan on cardiovascular events in high-risk patients intolerant to angiotensin-converting enzyme inhibitors: A randomised controlled trial. Lancet 2008, 372, 1174-1183. [PubMed]

40. Yusuf, S.; Sleight, P.; Pogue, J.; Bosch, J.; Davies, R.; Dagenais, G. Effects of an angiotensin-converting-enzyme inhibitor, ramipril, on cardiovascular events in high-risk patients. N. Engl. J. Med. 2000, 342, 145-153.

41. Zanchetti, A.; Bond, M.G.; Hennig, M.; Neiss, A.; Mancia, G.; Dal Palù, C.; Hansson, L.; Magnani, B.; Rahn, K.H.; Reid, J.L.; et al. Calcium antagonist lacidipine slows down progression of asymptomatic carotid atherosclerosis: Principal results of the European Lacidipine Study on Atherosclerosis (ELSA), a randomized, double-blind, long-term trial. Circulation 2002, 106, $2422-2427$. [CrossRef]

42. Beckett, N.S.; Peters, R.; Fletcher, A.E.; Staessen, J.A.; Liu, L.; Dumitrascu, D.; Stoyanovsky, V.; Antikainen, R.L.; Nikitin, Y.; Anderson, C.; et al. Treatment of hypertension in patients 80 years of age or older. N. Engl. J. Med. 2008, 358, 1887-1898. [CrossRef]

43. Parati, G.; Lombardi, C.; Hedner, J.; Bonsignore, M.R.; Grote, L.; Tkacova, R.; Lévy, P.; Riha, R.; Bassetti, C.; Narkiewicz, K.; et al. Recommendations for the management of patients with obstructive sleep apnoea and hypertension. Eur. Respir. J. 2013, 41, 523-538. [CrossRef] [PubMed]

44. Patil, S.P.; Ayappa, I.A.; Caples, S.M.; Kimoff, R.J.; Patel, S.R.; Harrod, C.G. Treatment of Adult Obstructive Sleep Apnea with Positive Airway Pressure: An American Academy of Sleep Medicine Clinical Practice Guideline. J. Clin. Sleep Med. 2019, 15, 335-343. [CrossRef]

45. Giles, T.L.; Lasserson, T.J.; Smith, B.J.; White, J.; Wright, J.; Cates, C.J. Continuous positive airways pressure for obstructive sleep apnoea in adults. Cochrane Database Syst. Rev. 2006, 3, Cd001106.

46. Ramar, K.; Dort, L.C.; Katz, S.G.; Lettieri, C.J.; Harrod, C.G.; Thomas, S.M.; Chervin, R.D. Clinical Practice Guideline for the Treatment of Obstructive Sleep Apnea and Snoring with Oral Appliance Therapy: An Update for 2015. J. Clin. Sleep Med. 2015, 11, 773-827. [CrossRef]

47. Aurora, R.N.; Casey, K.R.; Kristo, D.; Auerbach, S.; Bista, S.R.; Chowdhuri, S.; Karippot, A.; Lamm, C.; Ramar, K.; Zak, R.; et al. Practice parameters for the surgical modifications of the upper airway for obstructive sleep apnea in adults. Sleep 2010, 33, 1408-1413. [CrossRef]

48. Morgenthaler, T.I.; Kapen, S.; Lee-Chiong, T.; Alessi, C.; Boehlecke, B.; Brown, T.; Coleman, J.; Friedman, L.; Kapur, V.; Owens, J.; et al. Practice parameters for the medical therapy of obstructive sleep apnea. Sleep 2006, 29, 1031-1035.

49. Kartali, N.; Daskalopoulou, E.; Geleris, P.; Chatzipantazi, S.; Tziomalos, K.; Vlachogiannis, E.; Karagiannis, A. The effect of continuous positive airway pressure therapy on blood pressure and arterial stiffness in hypertensive patients with obstructive sleep apnea. Sleep Breath 2014, 18, 635-640. [CrossRef]

50. Hoyos, C.M.; Yee, B.J.; Wong, K.K.; Grunstein, R.R.; Phillips, C.L. Treatment of Sleep Apnea with CPAP Lowers Central and Peripheral Blood Pressure Independent of the Time-of-Day: A Randomized Controlled Study. Am. J. Hypertens. 2015, 28, 1222-1228. [CrossRef]

51. Huang, Z.; Liu, Z.; Luo, Q.; Zhao, Q.; Zhao, Z.; Ma, X.; Xi, Q.; Yang, D. Predictors of Blood Pressure Fall with Continuous Positive Airway Pressure Treatment in Hypertension with Coronary Artery Disease and Obstructive Sleep Apnea. Can. J. Cardiol. 2015, 31, 853-859. [CrossRef]

52. Yang, M.C.; Huang, Y.C.; Lan, C.C.; Wu, Y.K.; Huang, K.F. Beneficial Effects of Long-Term CPAP Treatment on Sleep Quality and Blood Pressure in Adherent Subjects with Obstructive Sleep Apnea. Respir. Care 2015, 60, 1810-1818. [CrossRef]

53. Schulz, R.; Mahmoudi, S.; Hattar, K.; Sibelius, U.; Olschewski, H.; Mayer, K.; Seeger, W.; Grimminger, F. Enhanced release of superoxide from polymorphonuclear neutrophils in obstructive sleep apnea. Impact of continuous positive airway pressure therapy. Am. J. Respir. Crit. Care Med. 2000, 162 Pt 1, 566-570. [CrossRef]

54. Zou, D.; Grote, L.; Eder, D.N.; Radlinski, J.; Hedner, J. A double-blind, crossover study of Doxazosin and Enalapril on peripheral vascular tone and nocturnal blood pressure in sleep apnea patients. Sleep Med. 2010, 11, 325-328. [CrossRef]

55. Pépin, J.L.; Tamisier, R.; Barone-Rochette, G.; Launois, S.H.; Lévy, P.; Baguet, J.P. Comparison of continuous positive airway pressure and valsartan in hypertensive patients with sleep apnea. Am. J. Respir. Crit. Care Med. 2010, 182, 954-960. [CrossRef] [PubMed]

56. Morimoto, T.; Gandhi, T.K.; Fiskio, J.M.; Seger, A.C.; So, J.W.; Cook, E.F.; Fukui, T.; Bates, D.W. An evaluation of risk factors for adverse drug events associated with angiotensin-converting enzyme inhibitors. J. Eval. Clin. Pract. 2004, 10, 499-509. [CrossRef]

57. Cove-Smith, J.R.; Kirk, C.A. CNS-related side-effects with metoprolol and atenolol. Eur. J. Clin. Pharmacol. 1985, 28 (Suppl. 1), 69-72. [CrossRef] [PubMed]

58. Nifedipine-Atenolol Study Review Committee. Nifedipine and atenolol singly and combined for treatment of essential hypertension: Comparative multicentre study in general practice in the United Kingdom. Br. Med. J. (Clin. Res. Ed.) 1988, 296, 468-472. [CrossRef]

59. Lacourcière, Y.; Asmar, R. A comparison of the efficacy and duration of action of candesartan cilexetil and losartan as assessed by clinic and ambulatory blood pressure after a missed dose, in truly hypertensive patients: A placebo-controlled, forced titration study. Candesartan/Losartan study investigators. Am. J. Hypertens. 1999, 12 Pt 1-2, 1181-1187.

60. Engbaek, M.; Hjerrild, M.; Hallas, J.; Jacobsen, I.A. The effect of low-dose spironolactone on resistant hypertension. J. Am. Soc. Hypertens. 2010, 4, 290-294. [CrossRef] 
61. Oparil, S.; Williams, D.; Chrysant, S.G.; Marbury, T.C.; Neutel, J. Comparative efficacy of olmesartan, losartan, valsartan, and irbesartan in the control of essential hypertension. J. Clin. Hypertens. (Greenwich) 2001, 3, 283-318. [CrossRef]

62. Thunström, E.; Manhem, K.; Rosengren, A.; Peker, Y. Blood Pressure Response to Losartan and Continuous Positive Airway Pressure in Hypertension and Obstructive Sleep Apnea. Am. J. Respir. Crit. Care Med. 2016, 193, 310-320. [CrossRef]

63. de Souza, F.; Muxfeldt, E.S.; Margallo, V.; Cortez, A.F.; Cavalcanti, A.H.; Salles, G.F. Effects of continuous positive airway pressure treatment on aldosterone excretion in patients with obstructive sleep apnoea and resistant hypertension: A randomized controlled trial. J. Hypertens. 2017, 35, 837-844. [CrossRef] [PubMed]

64. Muxfeldt, E.S.; Margallo, V.; Costa, L.M.; Guimarães, G.; Cavalcante, A.H.; Azevedo, J.C.; de Souza, F.; Cardoso, C.R.; Salles, G.F. Effects of continuous positive airway pressure treatment on clinic and ambulatory blood pressures in patients with obstructive sleep apnea and resistant hypertension: A randomized controlled trial. Hypertension 2015, 65, 736-742. [CrossRef]

65. Rotenberg, B.W.; Murariu, D.; Pang, K.P. Trends in CPAP adherence over twenty years of data collection: A flattened curve. J. Otolaryngol. Head Neck Surg. 2016, 45, 1-9. [CrossRef] 